KINGA MARULEWSKA

Instytut Politologii UMK

\title{
Eugenika w świetle idei postępu. Rozważania wokół fundamentów filozoficznych
}

I któż zatem mógłby wątpić, że postęp jest wielkim powszechnym kościołem XIX wieku, jedynym, jaki cieszy się prawdziwym autorytetem i bezkrytyczną wiarą?

E R N S T J Ü N G E R

hociaż współcześnie powszechnie postrzegana jako ponura aberracja nauki i kojarzona jedynie z Rassenhygiene nazistów, eugenika na początku dwudziestego wieku cieszyła się poważaniem, które możemy sobie spróbować wyobrazić, porównując do emocji wyzwalanych obecnie przez genetykę. Bliski związek pomiędzy tymi dwiema naukami - jedną powstałą w wieku dziewiętnastym, a realizowaną na początku dwudziestego i drugą, święcącą triumfy prawie dokładnie wiek później - podkreślany przez niektórych badaczy tematu skłania do głębokiego namysłu nad eugeniką. Być może bowiem stanowi ona klucz do zrozumienia współczesnych problemów, zwłaszcza bioetycznych, ale również tych dotyczących postępu nauk przyrodniczych i technicznych, a nawet jeśli nie klucz, to wskazówkę do ich interpretacji. Jest to o tyle ważne, że, jak zauważa A. Kerr, „genetycy (i popularyzatorzy genetyki) mają tendencję do odrzucania zarzutów o «eugeniczność» jako nieracjonalnych, strasznych i opartych o przesadzone wyobraże- 
nie na temat technicznych możliwości i władzy politycznej naukowców i doktorów"1.

W literaturze anglojęzycznej rozważania na temat eugeniki prowadzone są już od dłuższego czasu i niezwykle często powiązane z kwestiami, z jakimi borykają się czasy obecne. Brak jest natomiast systematycznego namysłu nad tą problematyką na polskiej niwie, a sporadycznie pojawiająca się literatura ogranicza się przeważnie do jednostronnych ujęć, kładących nacisk na nazistowską wersję tej „nauki o człowieku”. Chlubny wyjątek w tym względzie stanowi książka Magdaleny Gawin poświęcona polskiemu ruchowi eugenicznemu ${ }^{3}$.

Pragnienie ulepszenia człowieka, jakie opanowało świat zachodni na początku dwudziestego wieku, miało złożone przyczyny. Można z pewnością do nich zaliczyć powody natury społecznej - emancypacja mas wymusiła poszukiwania systemowych i stosowanych na skalę powszechną form rozwiązywania problemów takich jak ubóstwo, różnego rodzaju patologie i moralne niedomagania. Rozwiązanie musiało być skuteczne i dostępne dla każdego, a więc w istocie egalitarne; angażujące się coraz bardziej w działalność społeczną towarzystwa i stowarzyszenia stopniowo wymogły na państwie zainteresowanie na poziomie instytucjonalnym. Również rozwój nauk przyrodniczych oraz nauk o człowieku, jak socjologia czy psychologia, mógł dawać rychłą nadzieję na kontrolę, a w jej następstwie - poprawę natury ludzkiej. Marzenia o możliwości poprawienia „natury” coraz częściej okazywały się nie być mrzonkami, lecz realnie stojącymi przed społeczeństwem możliwościami, z których można było śmiało korzystać.

Najbardziej interesującym polem, jakie będzie przedmiotem refleksji w niniejszym tekście, są jednakże przyczyny natury filozoficznoświatopoglądowej. Postaram się pokazać, że eugenika nie była pseudonauką - makabryczną i pełną pychy rywalizacją z Bogiem, lecz bazowała na uzna-

1 A. Kerr, S. Cunningham-Burley, A. Amos, Eugenics and the New Genetics in Britain: Examining Contemporary Professionals' Accounts, „Science, Technology, \& Human Values”, Vol. 23, No. 2, 1998, s. 176. Wszelkie tłumaczenia - jeśli nie jest wskazane inaczej - dokonane są przez autorkę artykułu.

2 Literatura dotycząca eugeniki jest dość obszerna, by wspomnieć tylko następujące prace: L.S. Waterman; C.P. Blacker, Eugenics: Galton and After, Charles Duckworth, London 1952; F. Schenk, A.S. Parkes, The Activities of the Eugenics Society, „Eugenics Review”, Vol. 60, 1968, s. 142-161; M. Haller, Eugenics: Hereditarian Attitudes in American Thought, New Brunswick 1963; K.M. Ludmerer, Genetics and American Society: an Historical Appraisal, Baltimore 1972; D.K. Pickens, Eugenics and the Progressives, Nashville 1968; G. Allen, Genetics, Eugenics and Society: Internalists and Externalists in Contemporary History of Science, "Social Studies of Science", Vol. 6, 1976, s. 105-122.

3 M. Gawin, Rasa i nowoczesność: historia polskiego ruchu eugenicznego (1880-1952), Warszawa 2003. 
wanych wówczas niemal powszechnie naukowych podstawach. Łatwo byłoby poradzić sobie z eugenicznym dziedzictwem, przyklejając jej łatki «pseudonauki» bądź też «ideologii». Wydaje się jednak, że stanowiła ona kontynuację intelektualnych i społecznych prądów, jakie ją poprzedzały, a nawet jak można by nieostrożnie dodać - doskonałe ucieleśnienie utopijnych ${ }^{4}$ marzeń swych poprzedników. Nie była zatem nieoczekiwanym wykwitem na zdrowym ciele ludzkości, lecz stanowiła logiczną konsekwencję procesów również tych intelektualnych - które tkwiły korzeniami głęboko w przeszłości.

Tradycja filozoficzna, z którą, jak sądzę, wiąże się eugenika w sposób niezwykle ścisły, bazuje (czasem nie wprost) na idei postępu. Takie postawienie sprawy prowadzi do zasadniczej trudności: wpisanie eugeniki jako nauki (a więc czynności praktycznych) w pewną tradycję myśli wywołuje pytanie o to, w jaki sposób nauka - bądź co bądź przyrodnicza - w ogóle może zostać $\mathrm{w}$ taką historię wpisana. Eugenika z pewnością posiadała założenia natury filozoficznej dotyczącej podstawowych dla jej uprawiania kategorii, choć niekoniecznie musiała je wyrażać explicite. Owe filozoficzne założenia można uznać za część historii myśli. Myśl postępowa, jaka zgodnie z tezą artykułu stanowi korzenie eugeniki, posiadała mimo swej teoretyczności piętno aktywistyczne - nierzadko w założeniu miała stanowić pewien program do realizacji bądź też przewidywanie rzeczywistości w przyszłości. Condorcet pytając, „Na jakich drogach rodzaj ludzki będzie się doskonalić?" ${ }^{\text {, nie }}$ miał żadnych wątpliwości, że z pewnością ów postęp się dokona, bowiem „nieograniczone są możliwości doskonalenia się człowieka"6. Pragnienie postępu nie miało jednak pozostać teoretycznym projektem, lecz w zamierzeniach miało się wcielić w społeczną rzeczywistość.

Idea postępu jest „teorią, która zawiera w sobie syntezę przeszłości i przepowiednię co do przyszłości. Bazuje ona na interpretacji historii uznającej, że człowiek powoli posuwa się naprzód - pedetemtim progredientes w określonym i pożądanym kierunku, i wnioskuje, że ten postęp będzie trwał bez końca"". Początki tej idei trudne są do odnalezienia - jedni, w tym cyto-

Projekty eugeniki mieściłyby się w nurcie utopii heroicznych tj. takich, które za cel stawiają sobie zmianę świata tak, by odpowiadał ludzkim potrzebom. Idąc dalej, byłby to rodzaj utopii polityki, czyli projektów zakładających całościową reformę społeczeństwa. Por. szerzej J. Szacki, Spotkania z utopia, Warszawa 2000.

5 A.N. Condorcet, Szkic obrazu postępu ducha ludzkiego poprzez dzieje, przeł. E. Hartleb, dokończył J. Strzelecki, Warszawa 1957, s. 213.

Tamże, s. 243-244.

J.B. Bury, The Idea of Progress: an Inquiry into its Origin and Growth, Dover Publications, New York 1955, s. 5. 
wany John B. Bury, stanowczo twierdzą, że starożytni nie znali idei postępu ${ }^{8}$, inni, jak Robert Nisbet, doszukują się jej cienia w niektórych pismach Greków9. Stanowisko pośrednie zajmują E. Coreth i H. Schöndorf, twierdząc, iż „przekonanie, że istnieje stopniowy rozwój ludzkiej kultury i cywilizacji, pojawia się także już w starożytności, ale powszechna wiara w postęp jest typowo nowożytna. W tle idei postępu znajdują się przeważnie będące pod wpływem religijnym oczekiwania czasów ostatecznych" ${ }^{10}$. Spory te pozostawiamy jednak bez rozwiązania, ponieważ przekraczają one objętość niniejszego tekstu. Zasadnicze znaczenie będą mieli znacznie późniejsi niż antyczni przedstawiciele myśli postępowej - poczynając od zarania nowożytności, od którego „idea postępu jest nie marginesową, lecz konstytutywną ideą nowożytnego wizerunku nauki"11. Tym samym trzeba będzie nieco miejsca poświęcić związkom postępu z nauką, a w szczególności ich skrajnej formie tj. scjentyzmowi. Do przedstawicieli tak szeroko rozumianej idei postępu można zatem zaliczyć m.in. Francisa Bacona oraz Kartezjusza jako jej nowożytnych protoplastów, Bernarda Fontenelle'a, Jacquesa Turgota, Antoine'a Nicolasa Condorceta, Thomasa Malthusa, Johanna Gotfrieda Herdera, Immanuela Kanta, Georga Wilhelma Friedricha Hegla, Giambatistę Vico, ClaudeHenri'ego Saint-Simona, Augusta Comte'a oraz ewolucjonistów Charlesa Darwina oraz Herberta Spencera. Listę tę z pewnością można by było uczynić o wiele dłuższą.

Wstępną część stanowić będzie krótki rys historyczny eugeniki, ze szczególnym uwzględnieniem jej twórcy - Francisa Galtona. Natomiast związki eugeniki z ideą postępu zamierzam ukazać na dwóch zasadniczych płaszczyznach - jako kontynuację myśli: 1) opierającej się na wierze w postęp w i e d z y (eugenika jako naukowe ucieleśnienie „wiedzy o człowieku"); 2) postrzegającej postęp w kategoriach postępu c złow i e k a jako

8 „Może wydawać się szczególnie zaskakujące to, że Grecy, którzy byli tak płodni w spekulowaniu na temat ludzkiego życia, nie natrafili na ideę, która zdaje się nam tak prosta i oczywista jak idea Postępu" (Tamże, s. 7). Podobnie zresztą sądzili J. Baillie, F.M. Cornford oraz R.G. Collingwood.

9 „Czy ideę postępu można odnaleźć w klasycznej greckiej i rzymskiej myśli: ideę, że ludzkość powoli, stopniowo, lecz stale wspinała się z pierwotnego stanu kulturalnej deprywacji, ignorancji i niepewności na stale wyższe poziomy cywilizacji oraz że taki rozwój będzie kontynuowany, mimo okazjonalnych cofnięć, przez teraźniejszość do przyszłości? odpowiedzią na to pytanie jest dobitne tak, na co dowody przedstawię w niniejszym rozdziale. (R. Nisbet, History of Idea of Progress, New York 1980, s. 10). Zwolennikami tej teorii są m.in. M.I. Finley oraz W.K.C. Guthrie. Nisbet opiera swoją tezę na pismach Ksenofanesa, Hezjoda, Ajschylosa, Protagorasa, Tukidydesa, Platona oraz Arystotelesa. Por. szerzej na ten temat R. Nisbet, dz. cyt., rozdział I, s. 10-46.

10 E. Coreth, H. Schöndorf, Filozofia XVII i XVIII wieku, przeł. P. Gwiazdecki, Kęty 2006, s. 10.

11 P. Rossi, Zatonięcia bez świadka. Idea postępu, przeł. A. Dudzińska-Facca, Warszawa 1998, s. 45. 
jednostki oraz s p ołe c z e ń stw a jako całości. Te aspekty pozwalają ukazać $\mathrm{w}$ nowym świetle podstawowe założenia eugeniki, jednocześnie wskazując na ich głębokie korzenie i osadzenie w tradycji świata nowożytnego. Warto zaznaczyć, że uczynienie idei postępu osią rozważań nad eugeniką nie wyklucza oczywiście innych ujęć, nie rości sobie również pretensji do całościowego ukazania jej istoty ${ }^{12}$. Jest to pomysł płodny o tyle, o ile przede wszystkim pozwala umieścić eugenikę jako element łańcucha, konsekwencję pewnej myśli, a także ukazać zasadnicze aspekty idei postępu, które wpłynęły na to, jaki kształt mogła przybrać eugenika i jaki faktycznie przybrała w czasie swego królowania.

\section{Eugenika: definicja i rys historyczny}

Rozwój brytyjskiej eugeniki określają według D. MacKenziego 4 punkty zwrotne $^{13}$ : kryzys lat 80 . XIX wieku, który zbiega się z jej powstaniem, wojna burska (1889-1902), która doprowadziła do uznania i popularności eugeniki na forum społeczeństwa, I wojna światowa, która wyznacza okres instytucjonalnego okrzepnięcia oraz pojawienie się nazizmu, będące punktem, od którego eugenika - w formie z początku wieku - zaczęła chylić się ku upadkowi.

Wszystko rozpoczęło się w połowie dziewiętnastego wieku, a dokładnie w 1859 roku, kiedy Karol Darwin opublikował książkę, która - jak się później okazało - stała się punktem przełomowym nie tylko w biologii, lecz między innymi również w antropologii, teologii czy filozofii. Mowa o The Origin of Species ${ }^{14}$, której wydanie wywołało burzę w świecie nauki. Postawienie

12 Przykładem zupełnie odmiennego traktowania eugeniki i eksplikacji jej pojawienia się jest choćby koncepcja Donalda MacKenziego: „Uzasadnię, że eugenika powinna być postrzegana jako ideologia zawodowej klasy średniej (professional middle class) w szczególności raczej w «nowoczesnym» niż «tradycyjnym» sektorze. Idee eugeniczne wysunięto jako uzasadnienie pozycji społecznej zawodowej klasy średniej oraz jako argument dla poprawienia [jej statusu]. Jednocześnie program eugeniczny był postrzegany przez jego rzeczników jako rozwiązanie najbardziej naglących dostrzeganych problemów kontroli społecznej w brytyjskim społeczeństwie. Tym samym, był on wysuwany jako strategia klasy rządzącej, a wiarygodność eugeniki jako takiej strategii jest ważnym czynnikiem w wyjaśnianiu jej powstania i upadku. Idee eugeniczne mogą być uznane za zestaw narzędzi rozmieszczonych dla celów społecznych. Zostały podjęte, gdy uznano je za przydatne dla ich nosicieli, a później, gdy zmienione okoliczności sprawiły, że były mniej odpowiednie, zostały porzucone” (D. MacKenzie, Eugenics in Britain, „Social Studies of Science”, Vol. 6, No. 3/4, 1976, s. 501).

13 Tamże, s. 517

14 Pełny tytuł brzmi: On the Origin of Species by Means of Natural Selection, or the Preservation of Favoured Races in the Struggle for Life, jednak od szóstego wydania tj. od 1872 roku zmieniono tytuł na prostsze The Origins of Species. 
- rewolucyjnej, choć nie do końca nowej - tezy o ewolucji organizmów żywych, doprowadziło do rozwoju nowego spojrzenia na człowieka.

Praca Darwina miała również zasadnicze znaczenie dla Francisa Galtona, kuzyna autora 0 pochodzeniu gatunków, słusznie uważanego za bezpośredniego ojca eugeniki. Galton urodził się w 16 lutego 1822 roku $^{15} \mathrm{w}$ rodzinie „podwójnie” naukowej - Darwinowie zajmowali się głównie medycyną i przyrodoznawstwem, natomiast Galtonowie byli uznanymi producentami broni i bankowcami. Obydwie rodziny znano z zamiłowania do nauki, uprawianej czynnie poza aktywnością zawodową ${ }^{16}$. Francis już od najmłodszych lat uważany był za małego geniusza - szybko czytał, miał łatwość zapamiętywania, interesował się wieloma rzeczami. Studiował medycynę i matematykę, a po śmierci ojca oddał się podróżowaniu: zwiedził Europę Wschodnią, Egipt, a także Afrykę Południową. Zajmował się czynnie meteorologią, statystyką i geografią,.

Prawdziwym przełomem w jego życiu i zainteresowaniach była, jak sam przyznaje, właśnie praca Darwina: „Publikacja w 1859 roku pracy O pochodzeniu gatunków napisanej przez Karola Darwina stała się początkiem nowej epoki tak w moim własnym rozwoju umysłowym, jak i generalnie w myśli ludzkiej" ${ }^{17}$, podobne uczucia wyraził w liście pisanym bezpośrednio do kuzyna: „pojawienie się Twojej Origin of Species doprowadziło do prawdziwego kryzysu w moim życiu; Twoja książka zniosła przymus mojego starego przesądu jak nocny koszmar i była pierwszą, która dała mi wolność myśli” ${ }^{18}$. Nowe zainteresowania dały o sobie znać w 1865 roku, gdy Galton opublikował dwa pierwsze artykuły dotyczace dziedziczenia ${ }^{19}-$ Hereditary Talent and

15 F. Galton, The Memories of my Life, London 1908, s. 2.

16 „Jego dziadek ze strony matki, Erasmus Darwin, był niezwykle cenionym lekarzem (...)”. (M. Bulmer, Francis Galton: Pioneer of Heredity and Biometry, Baltimore 2003, s. 3); „Zainteresowanie nauką było żywe z obydwu stron rodziny. Samuel Galton był zapalonym naukowcem-amatorem, który przyczynił się do powstania teorii widzenia kolorów (...). Obydwaj panowie [Samuel Galton oraz Erasmus Darwin] byli członkami Towarzystwa Królewskiego oraz Towarzystwa Księżycowego w Birmingham, klubu, którego członkowie spotykali się w swych domach w czasie pełni (...)” (Tamże, s. 4). O dziadku Samuelu Galtonie - „Miał zdecydowanie zdolności statystyczne, kochając ustawianie wszystkich rodzajów danych w podobne linie odpowiedniej długości i często używając koloru dla ich rozróżnienia. Mój ojciec oraz inne dzieci Samuela Johna Galtona odziedziczyli ten zmysł w mniejszym lub większym stopniu (...)" (F. Galton, The Memories..., s. 3).

17 F. Galton, The Memories..., s. 287.

18 Reply of Francis Galton to Charles Darwin's letter of Dec., 23, 1869, w: K. Pearson, The life, letters and labours of Francis Galton, Cambridge 1914, rysunek (Plate II) pomiędzy między stronami 6-7.

19 J.A. Field, The Progress of Eugenics, „The Quarterly Journal of Economics”, Vol. 26, No. 1, 1911, s. 4; F. Galton, The memories..., s. 289. 
Character $^{20}$. Zajął się w nich kwestią przekazywania zdolności i inteligencji ze znanych rodziców na dzieci. Temat ten znacznie rozwinął w napisanej kilka lat później książce Hereditary Genius ${ }^{21}$ - objął tam swoimi rozważaniami sędziów, mężów stanu, parów, wojskowych, naukowców, poetów, muzyków, malarzy, duchownych czy absolwentów Cambridge, ale również wioślarzy i zapaśników. Głównym celem tak szczegółowych studiów nad zdolnymi rodzicami i ich dziećmi było pokazanie, że „naturalne zdolności człowieka są dziedziczone z podobnymi ograniczeniami jak forma i cechy fizyczne całego świata organicznego"22. Do interpretacji zgromadzonych danych autor Hereditary Genius zastosował metody analizy statystycznej. Prawdopodobnie wzorował się w tym na Quetelecie i jego koncepcji człowieka "przeciętnego" jednak - jak twierdzi K. Pearson - „chociaż prace Galtona zdają się naturalnie wypływać z prac Queteleta, to jednak jestem pełen wątpliwości co do tego, na ile wiele on zawdzięcza drobiazgowemu czytaniu wielkiego belgijskiego statystyka"24.

Gdyby poszukiwać daty, którą można by uznać za symboliczny moment powstania eugeniki, z pewnością byłby to rok 1883 . W pracy Inquiries into Human Faculty Galton po raz pierwszy użył pojęcia „eugeniczny” ${ }^{25}$, wyjaśniając cel swej książki: „Moim zamiarem jest poruszenie tematów mniej lub bardziej związanych z kształtowaniem rasy lub też - jak moglibyśmy to nazwać - z kwestiami eugenicznymi [eugenic] (...)”26. Wyjaśniając swój wybór w przypisie dodał: „To znaczy z problemami związanymi z tym, co określone jest po grecku, dosłownie eugenes, dobry z pochodzenia, obdarzony z urodzenia szlachetnymi przymiotami. To [pojęcie] i pokrewne słowa, jak eugeneia itp., są stosowane tak samo do ludzi, zwierząt i roślin. Bardzo pragniemy zwięzłego określenia na oznaczenie nauki o ulepszaniu pochodzenia, która w żadnym wypadku nie jest ograniczona do pytań o rozsądne kojarzenie par,

20 F. Galton, Hereditiary Talent and Character, MacMillian's Magazine, Vol. XII, 1865, s. 157-166, 318-327.

21 Pierwsze wydanie Hereditary Genius pojawiło się w 1869 roku.

22 F. Galton, Hereditary Genius. An inquiry into its laws and consequences, London 1892, s. 1.

23 Por. omówienie podstawowych założeń koncepcji Queteleta - J. Grygieńć, Adolfa Queteleta koncepcja człowieka przeciętnego, „Dialogi Polityczne”, nr 5/6, 2005, s. 131-141; J. Szacki, Fizyka spoteczna Queteleta, w: tegoż, Historia myśli socjologicznej, Warszawa 2005, s. 271-276.

24 K. Pearson, dz. cyt., Vol. 2, s. 12. Należy mieć jednak na uwadze, że być może ocena innowatorstwa Galtona dokonana przez Pearsona jest nieco przesadna, ponieważ Pearson był uczniem autora Hereditary Genius, a cała praca ma bez wątpienia - nie kwestionując ogromnej ilości informacji i źródeł - niezwykle pochlebna.

25 W pracy R. H. Johnson, Eugenics and so-called eugenics, "The American Journal of Sociology”, Vol. 20, No. 1, Jul. 1914, s. 99. błędnie podaje rok wydania tej pracy jako 1873 - zarówno Pearson (dz. cyt., Vol. 2, s. 249), jak i inni zgodnie twierdzą, że był to rok 1883.

26 F. Galton, Inquiries into Human Faculty and its Development, London-New York 1907, s. 17. 
lecz która, szczególnie w przypadku człowieka, bierze pod rozwagę wszystkie wpływy, które dają, choć w niewielkim stopniu, bardziej odpowiednim rasom lub odmianom krwi większą szansę szybkiego zwyciężania nad mniej odpowiednimi, niż mieliby oni w innym wypadku. Słowo eugenika dostatecznie wyraża tę ideę (...)"27. Tym samym zastąpił używany przez siebie wcześniej termin „viriculture”28. Dalsze rozważania definicyjne prowadził w opublikowanym w 1904 roku tekście Eugenika: jej definicja, zakres i cele ${ }^{29}$, gdzie określa eugenikę jako naukę, „która zajmuje się wszystkimi wpływami ulepszającymi wrodzone cechy rasy, w tym również takimi, które rozwijają te cechy w najwyższym stopniu" ${ }^{\prime 30}$. Etymologia słowa eugenika, bazując na połączeniu eu - dobry, genes - urodzony, jest dużo bardziej „szlachetna” w swoim wydźwięku niż termin „viriculture”. Jednocześnie Galton wyraził swoje przekonanie, że „ludzka eugenika zostanie uznana niebawem jako badania o najwyższym znaczeniu praktycznym"31.

Myśl o eugenice jako nauce o powszechnym uznaniu została jednak urzeczywistniona dopiero w XX wieku. Ów czas sprzyjał rozszerzaniu się eugenicznych poglądów i koncepcje Galtona wsparte działalnością jego ucznia - Karla Pearsona ${ }^{32}$ trafiały powoli na podatny grunt. Pearson był matematykiem, a od 1896 roku kierował katedrą Matematyki Stosowanej i Mechaniki na University College w Londynie. Niekwestionowanym liderem środowiska uznającego metody analizy statystycznej do analizy dziedziczności był oczywiście sam Galton, który wzmocnił jeszcze swoją pozycję zakładając w 1901 roku wraz z Pearsonem oraz Walterem Weldonem pismo „Biometrika". Pearson został zaproszony do współpracy, ponieważ wygłosił 19. listopada 1900 roku wykład pod tytułem National Life from the standpoint of scien$\mathrm{ce}^{33}$, w którym odnosił się do kwestii ważnych z punktu widzenia eugeniki.

27 Tamże, s. 17 przypis 1.

28 Tenże, Hereditary Improvement, „Fraser's Magazine”, Vol. 7, 1873, s. 119. Samo łacińskie znaczenie tego terminu, które można byłoby przetłumaczyć jako „uprawa ludzi” jest już samo w sobie niezwykle interesujące, zwłaszcza w kontekście motywów utworzenia tego neologizmu przez Galtona. Wskazuje ono na tendencje eugeniki i niezwykle trafnie oddaje jej charakter - o wiele lepiej, jak sądzę, niż „eugenika”.

29 Tekst ten dostępny jest w niniejszym numerze pisma: F. Galton, Eugenika: jej definicja, zakres i cele, „Dialogi Polityczne” nr 10, 2008, s. 17-21.

30 Tamże, s. 17.

31 Tenże, Inquiries into Human..., s. 44.

32 Co ciekawe, obecnie stosowane metody analizy statystycznej są w dużej części autorstwa Pearsona, który był matematykiem z wykształcenia i zamiłowania, a który po zetknięciu się z książką Galtona Natural Inheritance zainteresował się wykorzystaniem metod matematycznych do badania dziedziczności i ewolucji. W latach 1893-1912 napisał kilkanaście prac, zebranych w jednym dziele Mathematical Contributions to the Theory of Evolution, w których zajął się analizą regresji, korelacją oraz testem chi-kwadrat.

33 J.A. Field, dz. cyt., s. 17. 
Francis Galton do 1911 roku, w którym zmarł, wygłosił wiele wykładów - jak choćby Huxley Lecture of the Antrophological Institute of Great Britain and Ireland czy też adresowanych do Towarzystwa Socjologicznego i czynnie działał na rzecz uznania nowej gałęzi nauki, jaką jego zdaniem była eugenika.

Instytucjonalny rozwój eugeniki oraz jej rozprzestrzenianie się poza Wielką Brytanię na kraje europejskie oraz Stany Zjednoczone nabrały tempa z początkiem dwudziestego wieku. W latach 1900-1914 eugenika uzyskała oblicze instytucjonalne, głównie dzięki ustanowieniu Eugenics Laboratory na University of London oraz założeniu w 1909 Eugenics Education Society (EES) ${ }^{34}$. W 1904 roku Galton ufundował stypendium badawcze nad eugeniką, a w swoim testamencie zapewnił środki na powstanie katedry eugeniki na University College w Londynie. Pierwszym wyznaczonym przez samego Galtona następcą był Karl Pearson, który zajmował to stanowisko w latach 19111933. Również w 1904 roku z inicjatywy Galtona powstało w Wielkiej Brytanii Eugenics Record Office (ERO), na którego czele stanął także Pearson.

Jednocześnie eugenika przenosiła się na inne kraje. W Stanach Zjednoczonych otrzymała ona silne wsparcie ze strony naukowców. Do głównych przedstawicieli i zwolenników eugeniki na gruncie amerykańskim można zaliczyć Alexandra Grahama Bella (tego samego, który wynalazł telefon, jednak badał on również - co w większym stopniu zawierało się w zakresie zainteresowań eugenicznych - dziedziczenie głuchoty), Davida Starra Jordana (ichtiologa ze Stanford University), Charlesa Davenporta, Harrego Laughlina czy Amosa Warnera. Już w 1910 roku powstało (w USA) Eugenics Record Office (ERO), które przygotowało społeczne podłoże pod wprowadzenie nowego prawa imigracji z 1924 roku, ograniczającego napływ „obcej krwi” do Stanów Zjednoczonych. Ruch eugeniczny rozwijał się również w Niemczech, w krajach skandynawskich, Indiach, Kanadzie, Francji, Japonii, Afryce Południowej i innych państwach, jednakże ze względu na ograniczoną objętość pracy pominę tutaj rozwój historyczny poza Wielką Brytanią ${ }^{35}$. W 1912 roku zorga-

34 D. MacKenzie, dz. cyt., s. 503. Jeśli chodzi o profil społeczny członków towarzystwa: „Kierownictwo Eugenicznego Towarzystwa Edukacyjnego było zdominowane przez wykształconych członków klasy średniej grup zawodowych związanych z medycyną, nauczaniem akademickim i nauką. Członkowie pochodzili nie tylko z klasy średniej, lecz w dużym stopniu z intelektualnych, kreatywnych i związanych ze społeczeństwem zawodów".

35 Por. literatura na ten temat: P. Weingart, German Eugenics between Science and Politics, "Osiris", 2nd Series, Vol. 5, Science in Germany: The Intersection of Institutional and Intellectual Issues, 1989, s. 260-282; L. R. Graham, Science and Values: The Eugenics Movement in Germany and Russia in the 1920s, „The American Historical Review”, Vol. 82, No. 5, 1977, s. 1133-1164; A. Spektorowski, E. Mizrachi, Eugenics and the Welfare State in Sweden: The Politics of Social Margins and the Idea of a Productive Society, "Journal of Contemporary History”, Vol. 39, No. 3, 2004, s. 333-352; K. Repp, „More Corporeal, More Concrete”: Liberal 
nizowano Pierwszy Międzynarodowy Kongres Eugeniczny, kolejne odbyły się w 1921 i 1932 roku.

Warto wspomnieć również o zasadniczym rozgraniczeniu dokonanym w ramach eugeniki. Otóż funkcjonował - niemal od początku - podział na eugenikę pozytywną oraz negatywną. Eugenika pozytywna, a raczej mówiąc ściślej - pozytywne działania postulowane przez eugenikę, skupia się wokół wspierania rozmnażania jednostek posiadających dobre geny: wspieranie matek, dodatki rodzicielskie, zachęcanie do posiadania dzieci przez rodziny o dobrych genach, a w planach skrajnych - dobór par małżeńskich. Negatywny aspekt działań eugenicznych stanowi drugą stronę poprzedniego - polega na zapobieganiu płodzeniu dzieci przez osoby nie posiadające odpowiednich genów tj. osoby upośledzone, epileptyków itp., ale także społecznie niedostosowanych, jak złodzieje czy prostytutki.

Historia eugeniki nie jest wcale jednoznaczna - kryje się w jej wnętrzu wiele wątków przenikających się wzajemnie i zahaczających o zagadnienia pierwotnie pozostające $\mathrm{z}$ dala od głównego tematu. Jednakże głównym celem tego tekstu nie jest analiza historyczna, stanowi ona jedynie szkic pomocny przy zrozumieniu zjawiska i jednocześnie wprowadzenie w zasadniczą część rozważań. Mając świadomość skromności powyższego rysu i wskazanych w nim wątków, skupię się na relacji pomiędzy ideą postępu a eugeniką.

\section{Eugenika jako wyraz postępu wiedzy}

Eugenika rozpatrywana w kontekście postępu wiedzy ujawnia swoje powiązania na dwa sposoby. Z jednej strony jest ona ucieleśnieniem marzeń o nauce, która potrafiłaby uczynić z człowieka kogoś lepszego niż jest on „z natury”. Eugenika stanowiła zatem realizacje pragnień i przewidywań myślicieli, którzy, wyrażając swoją wiarę w postęp wiedzy i nauki, przewidywali pojawienie się tego typu możliwości. Mówiąc krótko, jest ona w tym kontekście wykonaniem myśli o postępie wiedzy. Natomiast z drugiej strony, eugenika jawi się jako kolejny element w historycznym łańcuchu wiążącym „nosicieli” idei postępu wiedzy przez wieki. Eugenika jako taka wpisuje się w nurt myśli opartej o wiarę w postęp wiedzy, ponieważ wśród jej założeń tkwi przekonanie o ogromie możliwości, jakie dopiero czekają ją jako naukę i które pozwolą na podjęcie działań obecnie nie do pomyślenia. Obydwa te wątki postaram się rozwinąć poniżej.

Humanism, Eugenics, and German Progressives at the Last Fin de Siecle, „The Journal of Modern History", Vol. 72, No. 3, 2000, s. 683-730. 
Wiara w postęp wiedzy towarzyszy ludzkości od nowożytności i powiązana jest ściśle z triumfem przyrodoznawstwa, które rzuciło wyzwanie Bogu i światu, próbując rozwikłać tajemnice wcześniej niedostępne ludzkiemu poznaniu. „Instynktowne przekonanie o istnieniu Porządku Rzeczy”36 stało się fundamentem nowożytnego światopoglądu naukowego, a „stojące wciąż przed wyobraźnią przekonanie, że istnieje jakaś czekająca na odkrycie tajemnica" ${ }^{\text {"37 }}$ - siłą napędową badań naukowych. Wraz z narodzinami nowożytnej nauki i kolejnymi sukcesami przyrodników, zaczęto wypatrywać w przeszłości nadejścia jeszcze większej wiedzy i jeszcze większych możliwości - wyrażone słowami Johna Wilkinsa przekonanie, że „przyjdzie taki czas, w którym praca przyszłych wieków ujawni takie rzeczy, które dzisiaj są okryte ciemnością. Sztuki nie doszły jeszcze do przesilenia. Umiejętność przyszłych czasów, z pomocą trudów przodków, będzie mogła osiągnąć poziom, którego my jeszcze nie osiągnęliśmy"38 - nie było odosobnione. Powszechne było przeświadczenie, że „ludzki umysł, gdy uwolni się od przesądów i zabobonów, a także zastosuje właściwe metody badań, jest w stanie rozwiązać wszystkie zagadki świata, odsłonić wszystkie tajemnice rzeczywistości”39. Obraz nauki, o jakim tutaj mowa, pojawił się w Europie między połową XVI wieku i końcem XVII stulecia ${ }^{40}$.

Umiłowanie starożytności jako złotego wieku powoli ustępowało przekonaniu o wyższości teraźniejszości nad przeszłością, a przyszłości nad teraźniejszością. Upadek dziejów nakreślony przez Hezjoda w Pracach $i$ dniach - dokonujący się poprzez wieki: złoty, srebrny, brązowy i żelazny z epoką herosów pomiędzy ostatnimi dwoma - związany był z rodzajami (rasami!) ludzi, żyjącymi w poszczególnych okresach, różniącymi się między sobą: pierwsi ludzie nie znali pracy, trudów, ani starości, a żyli z płodów ziemi, ostatni z kolei, do których zaliczył się sam autor - „w trudach i znojach ni we dnie, ni w nocy na chwilę nie spocznie" ${ }^{41}$, a za ich panowania na ziemi szerzyć się będzie bezwstyd i zatrata odwiecznych praw ${ }^{42}$. Takie rozu-

36 A.N. Whitehead, Nauka i świat nowożytny, przeł. M. Kozłowski, M. Pieńkowski OP, Kraków 1987, s. 24

Tamże, s. 35.

38 P. Rossi, dz. cyt., s. 59

39 E. Coreth, H. Schöndorf, dz. cyt., s. 137.

40 P. Rossi, dz. cyt., s. 43.

$41 \quad$ Hezjod, Prace i dnie, przeł. W. Steffen, Wrocław 1952.

42 R. Nisbet kwestionuje interpretację tego fragmentu Hezjoda jako upadku. Według niego należy wczytać się głębiej w Prace $i$ dnie: „Uważne czytanie samego mitu i umieszczenie go w powiązaniu z innymi tematami pracy Hezjoda, sugeruje coś zupełnie innego. Przede wszystkim, porządek przedstawiony przez Hezjoda nie jest w żadnym wypadku nieustającym pogarszaniem się ludzkości. Nie ma wątpliwości, że dla Hezjoda pierwsza rasa, rasa złota, była faktycznie czysta i szczęśliwa, chociaż była pozbawiona umiejętności i sztuk, 
mienie dziejów skutkuje chęcią „odgrzebania złota”, powrotu do epoki szczęśliwości, by ocalić to, co obecnie zostało zniszczone lub zapomniane. Przewrót nowożytny zasadniczo zmienił tę optykę ${ }^{43}$. Przeszłość była wprawdzie w cenie, ale wzrok skierowano ku czasom nadchodzącym. Co więcej, w przeciwieństwie do chrześcijaństwa, nie spoglądano w kierunku przyszłości poza ziemskim życiem, lecz w stronę realizowalnego w doczesności nieustającego ulepszenia. Myśl naukowa i techniczna zbliżyła się w tym aspekcie do wszelkich odmian millenaryzmów, czekających na nadejście Trzeciego Królestwa jeszcze na tym „łez padole”.

Wiedza stała się tym samym nie kontemplacją prawdy, lecz raczej władzą, panowaniem nad naturą, praktycznie stosowalną receptą. Coraz większe znaczenie zaczęły mieć korzyści, jakie można było z niej czerpać. Przywiązanie do faktów, przy jednoczesnym pragnieniu zmiany tych faktów, doprowadziło do związania się nauki z techniką. A przecież, jak się zdaje, „należą one do dwóch różnych kategorii: poznawania i działania" ${ }^{44}$, jedna ma za cel odkrycie prawdy (choć twierdzenie to można by opatrzyć wieloma zastrzeżeniami i wyjaśnieniami), druga natomiast praktyczną użyteczność. Dojrzała technika powstała wtedy, gdy człowiek zaczął rozumieć świat mechanistycznie $^{45}$, a więc około XVI wieku. Technika jest „przeciwieństwem przystosowania podmiotu do środowiska" ${ }^{46}$, ponieważ przystosowuje środowisko do człowieka, poddaje je jego woli i władzy. Jej status moralny wzbudza wątpliwości, ponieważ ,jako taka programu nie określa, inaczej mówiąc, technika otrzymuje z góry ustalony cel, który powinna osiągnąć" ${ }^{47}$. Technicyzacja nauki prowadzi zatem do zawieszenia zasad moralnych i beztroskiej dowolności. Problem miejsca techniki i jej związków z nauką w świecie jest zaciemniany - jak zauważa Hannah Arendt ${ }^{48}$ - przez „nadmierne skupianie się na usługach, jakie oddają ludziom maszyny" ${ }^{49}$. Tymczasem pomijanie in-

które z czasem zwiększyłyby materialne wygody. Lecz następna stworzona rasa (nie ma u Hezjoda sugestii co do genetycznego upadku ras) nie jest druga pod żadnym względem" (R. Nisbet, dz. cyt., s. 15).

43 Por. szerzej P. Rossi, dz. cyt., s. 43-97.

44 E. Agazzi, Dobro, zło i nauka. Etyczny wymiar działalności naukowo-technicznej, przeł. E. Kałuszyńska, Warszawa 1997, s. 55.

45 J. Ortega y Gasset, Rozmyślania o technice, przeł. H. Woźniakowski, w: tegoż, Bunt mas i inne pisma socjologiczne, Warszawa 1982, s. 274.

46 Tamże, s. 248

47 Tamże, s. 276

48 Hannah Arendt twierdzi, że „źródłem nowożytnej techniki nie jest ewolucja narzędzi, które człowiek zawsze wynajdywał w celu ułatwienia sobie pracy i wznoszenia świata rzeczy, lecz wyłącznie całkowicie nie-praktyczne poszukiwanie bezużytecznej wiedzy" (H. Arendt, Kondycja ludzka, przeł. A. Łagodzka, Warszawa 2000, s. 313).

49 Tamże, s. 167. 
nych aspektów nauki niż czysto praktyczny i użyteczny, „techniczny” może zwieść naukę na manowce przekonania o wszechwładzy i co więcej - o konieczności podporządkowania świata ludzkiego tejże samozwańczej władzy.

Owo podporządkowanie świata spraw ludzkich władzy nauki Stefan Amsterdamski nazwał mianem scjentyzmu. To zjawisko polega, zdaniem autora Kryzysu scjentyzmu, na określeniu pewnego „zespołu tez dotyczących społecznej wartości nauki i metody naukowej" ${ }^{50}$. Tak rozumiany scjentyzm nie polega na konkretnej metodzie (choć niezwykle często był związany z podejściem radykalno-empirycystycznym), lecz na określonej wartościującej opinii co do roli nauki w kulturze. „Dla scjentyzmu charakterystyczne było właśnie postulowanie, by społeczeństwo w całości akceptowało ten system wartości, którego realizacja stworzy najlepsze warunki dla uprawiania nauki"51. Nie chodzi tutaj zatem o konkretne filozoficzne czy metodologiczne wyznaczniki, lecz wizję roli nauki w społeczeństwie ${ }^{52}$. Szczególnie silne inklinacje $\mathrm{w}$ tak rozumianym kierunku scjentystycznym przejawiały nauki przyrodnicze. Ich przekonanie (często nie wyrażane explicite) o posiadaniu swoistego monopolu na słuszność zaowocowało w tendencjach „przyrodoznawczych" w naukach humanistycznych i społecznych, niejednokrotnie zmuszonych do udowadniania swej naukowości na przyrodniczą miarę. Miarą postępu było właśnie przeniesienie naukowego poglądu „z fizyki na psychologię, moralność i ludzkie życie społeczne" ${ }^{\text {33. }}$.

Rozpatrując w tak nakreślonym kontekście eugenikę - we wskazanym na początku tej części podwójnym aspekcie: realizacji prognoz oraz kontynuacji myśli - nie sposób nie zwrócić uwagi na kilka interesujących faktów. Eugenika $\mathrm{z}$ pewnością stanowiła ucieleśnienie marzeń o naukowym (w „przyrodoznawczym” rozumieniu) charakterze nauk o człowieku. Condorcet, pytając o drogi rozwoju rodzaju ludzkiego: czy dokona się on może „poprzez nowe odkrycia w dziedzinie sztuk i nauk (...), czy poprzez udoskonalenie się zasad postępowania i moralności praktycznej, czy wreszcie dzięki realnemu udoskonaleniu się intelektualnych, moralnych i fi-

\footnotetext{
50 S. Amsterdamski, Kryzys scjentyzmu, w: Wizje człowieka i społeczeństwa w teoriach $i$ badaniach naukowych, red. S. Nowak, Warszawa 1984, s. 312.

51 Tamże, s. 313.

52 „Uznanie $\mathrm{n}$ a u k i, p o z n a n i a naukowego, p r a w d z i w e g o poznania rzeczywistości, za naczelną wartość aksjologiczną - jest zasadą mającą daleko idące konsekwencje. $Z$ tej właśnie podstawowej zasady wartościującej (której zawsze można nadać postać normy lub postulatu), z jej bardzo ogólnej treści, można logicznie wyprowadzić cały szereg norm bardziej szczegółowych, odnoszących się do określonych odcinków rzeczywistości." J. Skarbek, Scjentyzm, w: Z. Musiał, J. Skarbek, B. Wolniewicz, Trzy nurty: racjonalizm - antyracjonalizm - scjentyzm, Warszawa 2006, s. 204.

53 F. Copleston, Historia filozofii. T. 6, Od Wolffa do Kanta, przeł. J. Łoziński, s. 10
} 
z y c z n y ch zdolności człowieka, które może być wynikiem udoskonalenia przyrządów zwiększających siłę tych zdolności i kierujących ich używaniem, bądźudoskonalenia samej naturalnej konstytucji człow i e k a [wyróżnienie KM]" ${ }^{54}$, miał nadzieję na powstanie możliwości, które realnym uczyniłyby naukowe i systematyczne ulepszenie człowieka - było to marzenie o poddaniu prawu postępu samej istoty ludzkiej. „Wiara w postęp Oświecenia ożywa znowu, lecz teraz wzmocniona poprzez techniczno-przemysłowy rozwój i postęp materialnej cywilizacji" ${ }^{55}$.

W pewnym sensie eugenice się to udało. Naukę o człowieku oparto bowiem nie na filozoficzno-religijnej antropologii, w której zbyt wiele było niejasności, gdybań, a mało konkretnych recept, lecz na solidnych naukowych podstawach, które - co więcej - dostarczały wskazówek przekładających się bezpośrednio na życie społeczne. W ten sposób nauka przezwyciężyła swoje ograniczenia, obdarowując niedostępnymi wcześniej środkami manipulacji człowieka.

Eugenika jako taka stanowiła również pewną kontynuację tradycji myśli postępowej. Jej przedstawiciele byli świadomi zasadniczej nowoczesności i rewolucyjności eugeniki, która również dla nich stanowiła wyraz postępu wiedzy. Ponieważ „istnieją zawsze jakieś założenia podstawowe, przyjmowane podświadomie" 56 , a "wydają się [one] tak oczywiste, że ludzie nie zdają sobie sprawy, co przyjmują za założenie, bowiem żaden inny sposób spojrzenia na sprawy nie przyszedł im nigdy na myśl” ${ }^{57}$, również przekonanie o postępie wiedzy miało swoje głębokie konsekwencje. Jak pisał Galton „nasza nauka jest już wystarczająco [rozwinięta], by usprawiedliwić podążanie do tego [tj. ulepszania ludzi] być może największego ze wszystkich celu" ${ }^{58}$. Co więcej, „nie możemy wątpić w istnienie wielkiej siły czekającej na to, by jej użyć i którą można pokierować z ogromną korzyścią, gdy tylko nauczymy się ją rozumieć i stosować" 59 . Nimb naukowości, jaki stał za eugeniką, przyczyniał się do postrzegania jej jako kolejnego etapu rozwoju wiedzy, wyższego, ale i bardziej wysublimowanego niż te, przez które ludzkość przechodziła dotychczas. Ona sama stanowiła dopiero początek procesu wzrostu wiedzy, który w wyższym stopniu miał się dopiero dokonać za życia przyszłych pokoleń, co należało rozpocząć już teraz.

\footnotetext{
A.N. Condorcet, Szkic obrazu postępu..., s. 213.

E. Coreth, P. Ehlen, J. Schmidt, Filozofia XIX wieku, przeł. P. Gwiazdecki, Kęty 2006, s. 126.

A.N. Whitehead, dz. cyt., s. 79

Tamże.

58 F. Galton, The Possible Improvement of the Human Breed, under the Existing Conditions of Law and Sentiment, w: tegoż, Essays in Eugenics, London 1909, s. 2

$59 \quad$ Tamże, s. 33.
} 
Jednak jak zauważył Ortega y Gasset, „progresywiści sądząc, iż osiągnęliśmy już taki poziom historyczny, na jakim nie do pomyślenia jest cofnięcie, oraz że mechanicznie będziemy zmierzać ku nieskończoności, osłabili spojenia ludzkiej ostrożności. W ten sposób powstały możliwości ponownego wtargnięcia barbarzyństwa na świat"60. Ulepszanie człowieka za pomocą nauki niebezpiecznie się do tego zbliżyło, gdy Galton napisał, że „jesteśmy usprawiedliwieni $\mathrm{w}$ podążaniu $\mathrm{w}$ stanowczym i pełnym nadziei duchu każdą ścieżką, która wydaje się prowadzić do tego celu [wyróż. $\mathrm{KM}{ }^{\prime \prime 61}$.

\section{Eugenika i postęp człowieka oraz społeczeństwa}

Sukces nauki na polach fizyki, matematyki czy chemii nieuchronnie prowadził do prób przeniesienia skuteczności nauk przyrodniczych na człowieka i społeczeństwo. Stanowiło to wyraz pragnienia doskonałości, które odnaleźć można przed epoką nowożytną: zarówno w starożytności, jak i w wiekach średnich. Definicję doskonałości podał już Arystoteles w Metafizyce, gdzie wyróżnił „trzy znaczenia wyrazu czy raczej trzy odcienie jednego znaczenia, ale w każdym razie trzy różne pojęcia doskonałości”"2: (A) dosko-

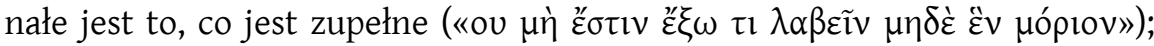
(B) doskonałe jest to, co jest tak dobre, że w swym rodzaju nie może być lep-

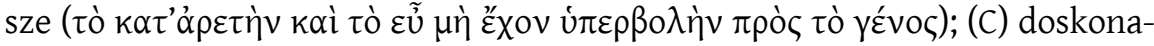

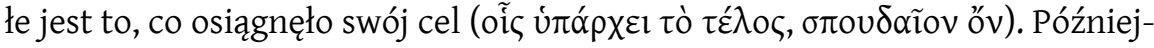
sze ujęcia doskonałości odwoływały się nierzadko do Arystotelesowskiego rozumienia ${ }^{63}$. Również nauka chrześcijańska pełna jest wezwań do doskonałości: na czele z „Bądźcie więc wy doskonali, jak doskonały jest Ojciec wasz niebieski” ${ }^{64}$ z Kazania na Górze ${ }^{65}$. Średniowieczna koncepcja doskonałości zakładała, że doskonałość jest wynikiem rozwoju, ponieważ to, co doskonałe staje się nim stopniowo. Jednocześnie podkreślano, że pełna doskonałość tu

J. Ortega y Gasset, dz. cyt., s. 259.

F. Galton, The Possible..., s. 33.

W. Tatarkiewicz, O doskonałości: wybrane eseje, Lublin 1991, s. 15.

6 W. Tatarkiewicz wymienia tutaj takie rozumienia doskonałości, jak: doprowadzone do końca, czyli zupełne (św. Tomasz i humaniści Odrodzenia); spełniające wszystkie właściwe sobie funkcje (Galen); to, co osiągnęło swój cel (św. Tomasz); to, co proste, jednolite, niezłożone (św. Ambroży); to, co harmonijne (myśliciele Odrodzenia); zgodne w różnorodności (Ch. Wolff, Baumgarten). Zob. szerzej W. Tatarkiewicz, dz. cyt., s. 19.

${ }^{64}$ Mt 5, 48. Tekst za Biblią Tysiąclecia, opracowaną przez zespół biblistów polskich z inicjatywy benedyktynów tynieckich (wydanie Poznań 2000).

65 Inne to: „bracia, radujcie się, dążcie do doskonałości, pokrzepiajcie się na duchu, bądźcie jednomyślni, pokój zachowujcie” (2 Kor 13,11), „Jego to głosimy, upominając każdego człowieka i ucząc każdego człowieka z całą mądrością, aby każdego człowieka przedstawić jako doskonałego w Chrystusie (Kol 1, 28). 
na ziemi naturalnymi środkami nie jest osiągalna, jak czynił to choćby św. Augustyn.

Doskonalenie jednostki wymagało ogromnego wysiłku i samozaparcia od niej samej. Odpowiedzialność za siebie jako istotę ludzką spoczywała na barkach każdego pojedynczego człowieka, zatem doskonalenie jednostki stawało się nieustannym, trwającym w każdym momencie egzystencji ćwiczeniem duchowym, wezwaniem do męstwa bycia ${ }^{66}$. Tak właśnie rozumiano zadanie i kondycję człowieka w starożytności i średniowieczu ${ }^{67}$. Była to metoda osiągania niezależności, wolności wewnętrznej, zmiana uległości namiętnościom we władzę nad sobą w pewnym określonym z góry celu - dla Greków było to wzór doskonałości mędrca, dla chrześcijan - dobre życie zgodne z Ewangelią.

Nowożytna doskonałość podbudowana naukowo różniła się zasadniczo od nakreślonego powyżej rozumienia poprzedników. Różniła się według mnie w dwóch punktach - po pierwsze, była doskonałością bez granicy czy celu, jej celem było nieustanne doskonalenie dla samego doskonalenia, bez uwagi na cel, któremu miałoby ono służyć; po drugie natomiast - w odróżnieniu od chrześcijaństwa, umiejscawiała marzenie o doskonałości w rzeczywistości ziemskiej. Marzenie o przeniesieniu dokonań nauk ścisłych wspierane siłą autorytetu przyrodników stopniowo urzeczywistniało się również w naukach o człowieku. Opierały się one na założeniu, że ,jako istnienie w świecie człowiek stanowi przedmiot poznawalny" ${ }^{68}$ i można go opisać w kategoriach nauk, którym dotychczas broniono dostępu do człowieka.

${ }_{66}$ W duchu określenia P. Tillicha: P. Tillich, Męstwo bycia, przeł. H. Bednarek, Poznań 1994.

67 Dzięki Filonowi z Aleksandrii znamy dziś dwie listy ćwiczeń starożytnych. Jedna z nich zawiera poszukiwanie, badanie pogłębione, lekturę, słuchanie, uwagę, panowanie nad sobą, obojętność na rzeczy obojętne, druga lekturę, medytacje, leczenie namiętności, wspomnienia tego, co dobre, panowanie nad sobą, spełnianie obowiązków. Szkoły greckie starały się wyposażyć swoich uczniów w oręż, jakim jest celna myśl lub zasada, zawarta w kilku słowach i łatwa do zapamiętania, po to, by w odpowiednim momencie móc przywołać ją z pamięci. Te ćwiczenia duchowe przygotowują człowieka na chwilę, kiedy jakaś sytuacja, której możemy nie sprostać, zjawi się w naszym życiu. Ślady takich materiałów na lektury dla adeptów trudnych sztuk filozofii znajdujemy u Seneki i Plutarcha, np. O spokoju duszy, o panowaniu nad gniewem, o ciekawości, o fałszywym wstydzie, O gniewie, o bezczynności. Por. szerzej P. Hadot, Filozofia jako ćwiczenie duchowe, przeł. P. Domański, Warszawa 2003.

68 K. Jaspers, Wprowadzenie do filozofii, przeł. A. Wołkowicz, Siedmioróg, Wrocław 2004, s. 45. „Powtarzam raz jeszcze: jako istnienie w świecie człowiek stanowi przedmiot poznawalny. Tak więc na przykład teorie rasowe pojmują człowieka w jego poszczególnych odmianach, psychoanaliza bada jego podświadomość i jej oddziaływanie, marksizm widzi w nim istotę żywą, zdolną do produktywnej pracy, która daje ludziom władzę na przyrodą i skłania ich do życia we wspólnocie (...) Te drogi poznania pozwalają wprawdzie zrozumieć pewne aspekty człowieczeństwa, pewne rzeczywiście zachodzące procesy - ale w żadnym razie nie człowieka w całości" (Tamże). 
Oświecenie francuskie, szkockie i niemieckie przygotowało grunt pod wiedzę o człowieku w formie ścisłej nauki, dokonując ponownego określenia natury ludzkiej. Mimo oczywistych różnic pomiędzy nurtami w poszczególnych krajach, pewne problemy oraz odpowiedzi na nie znaleźć można wszędzie. Postrzeganie człowieka jako biologicznego organizmu widoczne jest u Holbacha, gdy pisał, że „społeczeństwo jest całością utworzoną przez połączenie się większej liczby rodzin i jednostek, zjednoczonych w celu łatwiejszego zaspokajania swoich potrzeb, zapewnienia upragnionych korzyści i wzajemnej pomocy, a zwłaszcza - możności bezpiecznego korzystania z dóbr, jakich dostarczyć im może przyroda i własna pomysłowość" 69 . Idąc dalej, stwierdzał: „Jeżeli spojrzymy na człowieka z właściwego punktu widzenia (...) zobaczymy, że zjawiska świata moralnego podlegają tym samym prawom, co zjawiska świata fizycznego"70. Condorcet stworzył matematykę społeczną, polegającą na stosowaniu $\mathrm{w}$ analizie procesów społecznych rachunku prawdopodobieństwa, co miało umożliwić ich przewidywanie ${ }^{71}$. Pomysł zaprzęgnięcia matematyki i statystyki do opisu i przewidywania zjawisk z dziedziny spraw ludzkich wykorzystany został później w eugenice zarówno sam Galton, jak i Pearson posługiwali się matematyką, aby podbudować swe tezy ścisłymi danymi.

Widoczna jest w oświeceniu fascynacja Newtonowskim wzorem nauki jako wzorem uniwersalnym - jak pisał David Hume „działania ludzkie mają swój ogólny bieg naturalny zupełnie tak samo, jak operacje słońca i klimatu. I różne narody czy osoby poszczególne mają również charakter swoisty, a jednocześnie i pewne rysy wspólne wszystkim ludziom. Znajomość tych rysów opiera się na obserwowaniu niezmiennej prawidłowości w działaniach, które z nich wypływają (...)"72. W podkreślaniu biologicznej strony natury człowieka wtórował Kant w Krytyce praktycznego rozumu: „dwie rzeczy napełniają umysł coraz to nowym i wzmagającym się podziwem i czcią, im częściej i trwalej nad nimi się zastanawiamy: niebo gwiaździste nade mną i prawo moralne we mnie. (...) Pierwszy widok[, widok] nieskończonej mnogości światów niejako unicestwia moją ważność jako zwierzęcego stworzenia, które musi z powrotem zwrócić materię, z której się poczęło, planecie ([będącej] jedynie punktem we Wszechświecie), gdy skończy się krótki czas, przez któ-

69 P-H. d'Holbach, System przyrody, czyli prawa świata fizycznego i moralnego, przeł. J. Jabłońska, H. Suwała, t. 1, Warszawa 1957, s. 186.

70 Tamże, s. 295.

71 A.N. Condorcet, Matematyka społeczna, w: B. Baczko, Filozofia francuskiego Oświecenia, Warszawa 1961, s. 311-315.

72 D. Hume, Traktat o naturze ludzkiej, przeł. Cz. Znamierowski, t. 2, o uczuciach, Warszawa 1963, s. 172-173. 
ry było (nie wiadomo, w jaki sposób) obdarzone siłą życiową"73. Tym samym Kant łączy biologiczną i moralną naturę człowieka w jedną całość - człowiek jako byt przyrodniczy podlega prawom konieczności, natomiast w sferze moralnej jest wolny.

Kolejnym krokiem był ewolucjonizm, łączący biologiczne ujęcie natury ludzkiej z ideą postępu. Ewolucjonizm opierał się na założeniu, że świat ludzki jako część świata przyrody podlega prawom przyrodniczym, a zatem - jak pisał E. Tylor - „,nasze myśli, pragnienia i działania rządzą się prawami równie określonymi jak prawa rządzące ruchem fal, łączeniem się kwasów i zasad czy też wzrostem roślin i zwierząt" ${ }^{\text {"74 }}$. Darwinizm społeczny, z którego - jak się zdaje - korzystała eugenika inspirowana przez jego podstawowe założenia, a który stanowił przeniesienie tez ewolucjonizmu na grunt zjawisk społecznych, nie był jednak pierwszą próbą określenia praw rozwoju społeczeństw. Najważniejsze koncepcje rozwoju społeczeństw powstały przed teorią Darwina i miały swoje źródła w myśli XVIII i połowy XIX wie$\mathrm{ku}^{75}$, do których można zaliczyć Malthusa ${ }^{76}$, ale również oświeceniowe teorie rozwoju. Jak słusznie zauważył James C. Welling, „istnieli maltuzjaniści przed Malthusem"77. Przedstawicielami teorii rozwoju, o jakich mowa, byli m.in. Claude-Henri Saint-Simon ${ }^{78}$, August Comte ${ }^{79}$ czy Herbert Spencer $^{80}$. Od

73 I. Kant, Krytyka praktycznego rozumu, przeł. J. Gałecki, Warszawa 2004, s. 256-257.

74 E.B. Tylor, Primitive Culture. Researches into the development of Mythology, Philosophy, Religion, Art and Custom, t. 1, London 1871, s. 2, za: J. Szacki, Historia..., s. 284.

75 J. Szacki, Historia..., s. 281.

76 Na temat teorii Malthusa wyrażonej w An Essay on the Principle of Population zobacz szerzej: S. M. Levin, Malthus and the Idea of Progress, „Journal of the History of Ideas”, Vol. 27, No. 1, 1966, s. 92-108; C. L. Behar, Malthus and the Development of Demographic Analysis, „Population Studies", Vol. 41, No. 2, 1987, s. 269-281. Rola Malthusa w kontekście teorii ewolucyjnej jest wyczerpująco opisana w tekście: R. M. Young, Malthus and the Evolutionists: The Common Context of Biological and Social Theory, „Past and Present”, No. 43, 1969, s. 109-145. Intelektualne związki pomiędzy Malthusem a Darwinem opisał natomiast P. Vorzimmer, Darwin, Malthus, and the Theory of Natural Selection, "Journal of the History of Ideas", Vol. 30, No. 4, 1969, s. 527-542.

77 J. C. Welling, The Law of Malthus, „American Anthropologist”, Vol. 1, No. 1, 1888, s. 1.

78 Wyróżnił on trzy systemy wierzeń panujących w społeczeństwie: teologiczny, metafizyczny oraz pozytywny, czyli naukowy. Wskazał również na dwa systemy organizacji społecznej tj. feudalny, czyli militarny oraz industrialny. Por. C-H. Saint-Simon, Pisma wybrane, t. 1 i 2 , tłum. S. Antoszczuk, Warszawa 1968.

79 Podobnie jak Saint-Simon, którego przez pewien czas był sekretarzem, wskazał na prawo trzech stadiów tzn. teologicznego, metafizycznego oraz naukowego (pozytywnego). Zob. A. Comte, Rozprawa o duchu filozofii pozytywnej, przeł. J. K., Kęty 2001, s. 15-26.

80 „I tak jak biologia odkrywa pewne ogólne cechy rozwoju, struktury i funkcji występujące we wszystkich organizmach, pewne inne cechy występujące tylko w niektórych ich określonych grupach i pewne jeszcze inne cechy występujące tylko w niektórych podgrupach, tak i socjologia musi poznać prawdy społecznego rozwoju, struktury i funkcji, z których jedne są powszechne, inne ogólne, jeszcze inne szczegółowe” (H. Spencer, The Study of 
darwinizmu - jak już wskazałam - tylko krok do eugeniki. Także ona silnie inspirowana była zarówno biologizmem, opierała się przecież na biologicznych aspektach istoty ludzkiej, jak i przesiąknięta ideą postępu.

Ciekawy w nakreślonym powyżej kontekście jest fakt, że wielu eugeników zauważało symptomy upadku(!) pewnych grup społecznych, któremu poprzez eugeniczne działania - starali się zapobiec bądź też zminimalizować jego konsekwencje. Rozmnażanie złodziei, upośledzonych umysłowo czy epileptyków stanowiło zagrożenie dla społeczeństwa jako całości. Zgodnie z prawami dziedziczenia, cechy te mogły ulec jedynie niewielkiej poprawie u dzieci, częściej zaś były po prostu przenoszone. Sprzyjający „klimat opinii" ${ }^{11}$ dla tego typu rozważań powstał wraz z pojawieniem się mas na scenie publicznej. Pesymistyczne diagnozy stanu obecnego dokonywane przez J. Ortegę y Gasseta w Buncie mas czy też Zmierzchu Zachodu Oswalda Spenglera były wyrazem niepokojącego stanu części społeczeństwa. Podczas gdy społeczeństwo znajdowało się, jak sądzono, na ścieżce postępu, korzystając ze zdobyczy nauki i techniki, pewne jednostki czy też całe grupy społeczne stanowiły elementy niepożądane $\mathrm{z}$ dwóch względów: były dysfunkcjonalne w stosunku do całości, ale też były nośnikami niechcianych cech, które w przyszłości mogły się również ukazać w potomkach.

W wyraźny sposób zatem eugenika łączy się z ideą postępu człowieka i społeczeństwa, stanowiąc w dużym stopniu dziedzictwo myśli oświecenia dotyczącej postępu, ale również wypływającej z niego dziewiętnastowiecznej wiary w rozwój społeczny zgodnie z prawami ewolucji biologicznej.

\section{Zakończenie}

Powyższa prezentacja istoty eugeniki $\mathrm{w}$ świetle idei postępu pozwala na ogólną konkluzję dotyczącą związków pomiędzy tymi dwoma zjawiskami. Przede wszystkim należy stwierdzić, iż eugenika w widoczny sposób wiąże się z prądami intelektualnymi od przełomu nowożytności począwszy, opierając się - przeważnie nieświadomie - na bardzo wielu nurtach i tradycjach myślowych. Próbując dociec źródeł eugeniki, trzeba zmierzyć się nie tylko

Sociology, London 1880, s. 58-59 za: J. Szacki, Historia..., s. 297). Spencer wyróżnił dwa typologiczne stadia rozwoju: militarne oraz industrialne.

81 „Wyrażenie to [tj. klimat opinii] zostało ukute przez Josepha Glanvilla (1638-1680), a zyskało nową popularność, kiedy Alfred N. Whitehead podjął je na nowo w swej książce Nauka i świat wspótczesny (1925), natomiast, w ślad za inicjatywą Whiteheada, zmiany tego nowożytnego klimatu od siedemnastego wieku, stały się przedmiotem przenikliwych i rozległych badań Basila Willey'a nad tłem (Background), rozpoczętych w 1934 roku" (E. Voegelin, O studiach klasycznych, przeł. M.J. Czarnecki, „Dialogi Polityczne”, nr 9, 2008, s. 122). 
z popularnymi przesądami bądź też niewiedzą, ale również z szerokością tradycji myślowej, do której ona przynależy.

Eugenika stanowiła wykwit - straszny, ale wcale nie zaskakujący prądów nowożytności, począwszy od renesansowego rozkwitu nauki, poprzez oświeceniowe projekty ulepszenia ludzkości, aż do dziewiętnastowiecznego biologizmu. Idea postępu, która przejawia się we wszystkich tych aspektach, w sposób wyraźny wskazuje na połączenia pomiędzy eugeniką a wspomnianymi nurtami. Wiara w postęp wiedzy, jak i postęp człowieka oraz społeczeństwa tkwiły u jej podstaw. Mimo, że idea postępu według niektórych badaczy znana była już w starożytności (Nisbet), to zasadniczą linię podziału możemy postawić właśnie na granicy starożytność-nowożytność.

Pozostaje jeszcze odpowiedzieć na pytanie, w jaki sposób idea postępu eugeniki pozwala zinterpretować zjawiska neoeugeniczne czy też - jeśli posłużyć się współczesną terminologią — genetyczne? Obserwujemy tendencje, które stanowią ciąg dalszy projektów eugenicznych, choć odrzuciły jej nazwę: selekcja ze względu na zdrowie lub uszkodzenie płodu w łonie matki i dopuszczanie ewentualnej aborcji czy też banki nasienia i komórek jajowych są tego przykładem. W najwyraźniejszym stopniu widać je w działaniach dotyczących posiadania dzieci. Postęp wiedzy, pozwalający wykryć w bardzo wczesnej fazie niektóre schorzenia, przyniósł ze sobą również możliwość decyzji co do urodzenia lub też nie chorego dziecka. Samotne kobiety mogą wybrać sobie dawcę spermy z banku nasienia pod względem bardzo wielu kryteriów - inteligencji, umiejętności czy talentów. W przypadku zapłodnienia in vitro wybiera się najsilniejszy, najlepiej przystosowany zarodek po to, by umieścić go następnie w łonie matki.

W stosunku do eugeniki z początku dwudziestego wieku zachodzi jednak zasadnicza różnica. Projekty eugeniczne wyrastały z dążeń prospołecznych, „kolektywistycznych”, mających na celu rozwój społeczeństwa jako całości, podbudowane były biorącym się jeszcze z oświecenia szlachetnym pragnieniem ulepszania organizmu społecznego. Tymczasem współczesna genetyka $^{82}$ przeniosła możliwości, dostępne wówczas jedynie na poziomie instytucji publicznych takich jak szpitale dla upośledzonych, przytułki, przychodnie lekarskie, poradnie itd., do dyspozycji poszczególnych jednostek. O ile posiadają do tego środki, owe jednostki mogą podejmować decyzje co do chęci posiadania dziecka (antykoncepcja), jego zdrowia (aborcja), płci, a nawet poszczególnych jego cech, jak kolor oczu czy włosów (wybór genów). To nastawienie na indywidualne decyzje jednostek stanowi zasadniczą

82 Por. T. Sahaj, XIX- $i$ XX-wieczna eugenika społeczna w ujęciu historyczno-filozoficznym, „Archiwum Historii Filozofii i Myśli Społecznej”, nr 50-51, 2006, s. 277-294, zwłaszcza s. 288 i nn. 
różnicę w stosunku do początków dwudziestego wieku. Brak jest instytucjonalnych narzędzi wymuszających np. sterylizację czy aborcję. Uzasadnione zatem wydaje się używanie w stosunku do współczesnej genetyki krajów zachodnich terminu Jürgena Habermasa „eugenika liberalna”"3. Jednak eugenika liberalna nie znajduje się na przeciwległym krańcu w stosunku do eugeniki z początków dwudziestego wieku; stanowi raczej, jak mi się wydaje, inną jej formę, gdzie warunki życia zostały zastąpione przez posiadane środki. Im większą ilością środków dysponuje jednostka, tym więcej może zaoferować swemu potomstwu, tj. tym lepsze potomstwo może posiadać. Można nawet pokusić się o nieco przesadne twierdzenie, że genetyka jest „dziką eugeniką": jej stosowanie nie jest poddane żadnej kontroli, nie wiadomo również jakie geny są „transmitowane” - czy są to geny geniuszy czy jedynie rynkowych spryciarzy.

Eugenika również dzisiaj stanowi aktualne odniesienie, zarówno przez swój własny charakter, jak i związek ze współczesnymi problemami. Nieuchronnie wywołuje również pytania o etyczność przedsięwzięć, mających na celu modyfikację i ulepszenie ludzkości poprzez ingerencję w biologiczną stronę istoty ludzkiej. Idea postępu jest silnie zakorzeniona w nowożytnym sposobie myślenia o świecie, społeczeństwie i samym człowieku. O ile jednak łatwo jest ocenić techniczną skuteczność podejmowanych przez naukowców działań, o tyle często w ferworze odkryć naukowych umyka gdzieś całościowe postrzeganie człowieka, które tak charakterystyczne było dla starożytnych i średniowiecznych myślicieli. Nic dziwnego, że na podstawowe problemy moralne nie potrafimy dziś znaleźć odpowiedzi, skoro argumentacja odbywa się ze stanowisk niesprowadzalnych do siebie nawzajem, jak twierdzi A. MacIntyre ${ }^{84}$. Być może powinniśmy zatem ponownie spojrzeć w przeszłość i „odgrzebać złoto”, które pozwoli nam zmierzyć się z możliwościami współczesnej neoeugeniki.

K I N G A M A R U L E W S K A

33 J. Habermas, Przyszłość natury ludzkiej. Czy zmierzamy do eugeniki liberalnej?, Warszawa 2003.

84 A. MacIntyre, Dziedzictwo cnoty: studium z teorii moralności, przeł. A. Chmielewski, Warszawa 1996. 


\section{Abstract}

This article focuses on the philosophical foundations of eugenics with special attention paid to the category of progress. First and foremost, it maintains that although the moral and scientific core of eugenics has been commonly perceived as pseudo-science or ideology, there were strong tendencies in this intellectual movement, which allow to point out its connection with the preceding social and philosophical tradition. Secondly, it stresses the role of the progressive thought, which ensured a broad basis of support for social policies appealing to the concern for national popular quality. I examine two distinct, however closely related, components in the idea of progress: (1) progress comprehended as the development of knowledge and science; (2) advancement of human being and society. This approach, which concentrates on the characteristics of eugenics in context of "progress", diverts attention from popular view of the Nazi's eugenics and racial hygiene to philosophically deep roots of the dream about the fittest human, providing yet another reason for interest in eugenics.

The article suggests that with the reawakening of neoliberal version of eugenics (Habermas), it is more important to clearly define borders of the values of productivity, social efficiency and the idea of a healthy society. Thus a history of eugenics as phenomenon and history of philosophical presuppositions of eugenics can provide an awareness and appropriate understanding of the foundations of the modern world. 